\title{
Physical, Chemical, Morphological and Mineralogical Characterization Surface and Subsurface in Hydromorphic and Non-hydromorphic Soil of the Central Amazon
}

\author{
João Batista Dias Damaceno ${ }^{1}$, Wellington Gomes da Silva ${ }^{1}$, Hedinaldo Narciso Lima ${ }^{1}$, \\ Newton Paulo de Souza Falcão ${ }^{2}$, Felipe de Jesus Padilha ${ }^{3}$, Ari Batista da Costa Junior ${ }^{1}$, \\ Jhonny Kelvin Dias Martins ${ }^{4}$, Matheus Miranda Caniato ${ }^{5}$, Fábio Régis de Souza ${ }^{6}$, \\ Wildson Benedito Mendes Brito ${ }^{1} \&$ Carlos Alberto Franco Tucci ${ }^{1}$ \\ ${ }^{1}$ Federal University of Amazonas, Amazonas, Manaus, Brazil \\ ${ }^{2}$ National Institute for Amazonian Research, Amazonas, Manaus, Brazil \\ ${ }^{3}$ Amazon Biotechnology Center, Amazonas, Manaus, Brazil \\ ${ }^{4}$ Federal University of Espirito Santo, Espirito Santo, São Mateus, Brazil \\ ${ }^{5}$ Federal Institute of Amazonas, Amazonas, Manaus, Brazil \\ ${ }^{6}$ Federal University of Rondônia, Rondônia, Rolim de Moura, Brazil \\ Correspondence: João Batista Dias Damaceno, Federal University of Amazonas, Amazonas, Manaus, Brazil. \\ E-mail: joaodiasrm@gmail.com
}

Received: February 9, 2020

Accepted: March 6, 2020

Online Published: March 15, 2020

doi:10.5539/jas.v12n4p245

URL: https://doi.org/10.5539/jas.v12n4p245

\begin{abstract}
Amazonian soils have some physical, chemical and mineralogical differences, understanding the differences is important to understand the behavior of nutrients in the soil, especially phosphorus. The study was carried out in two types of soils: a Hydromorphic soil profile and a Non-hydromorphic soil profile in the Central Amazon region of Brazil, located in the metropolitan area of Manaus. Five depths were sampled: 0.00-0.05; 0.05-0.1; 0.1-0.2; 0.2-0.4; and 0.4-0.6 m. Physical, chemical, mineralogical and morphological attributes of both soils were studied. With the exception of clay, the levels of sand and silt remained stable in depth. The levels of organic matter gradually decrease in depth. The $\mathrm{pH}$ in water and in $\mathrm{KCl}, \Delta \mathrm{pH}$, point of zero load, were similar between the surface and subsurface soils. $\mathrm{Al}^{3+}, \mathrm{H}^{+}+\mathrm{Al}^{3+}, \mathrm{CECt}$, CECT and clay activity were similar in Non-hydromorphic soil and increase in surface $(<0.2 \mathrm{~m})$ and stabilize in subsurface $(>0.2 \mathrm{~m})$. In both soils, the bases are reduced in subsurface $(>0.2 \mathrm{~m})$. Aluminum and iron oxalate reduce with greater expressiveness in Non-hydromorphic soil. Aluminum and dithionite iron exhibit the same behavior. The levels of Goethite (Gt) and Hematite (Hm) are high in depth in the Non-hydromorphic soil and decrease in the Hydromorphic soil. There are sensitive distinctions between soils, due to the imposed edaphoclimatic conditions.
\end{abstract}

Keywords: oxisol, gleysol, Amazonian soils, fertility

\section{Introduction}

The soils of the Amazon, mainly those of the Central Amazon, are predominantly formed by the weathering of sedimentary rocks. The characteristics of the source material combined with the intense edaphoclimatic action typical of the region of origin, in general, deep soils and without significant physical impediments, however chemically poor, which in part represent a barrier to local development (Sanchez et al., 1982; Falesi, 1984; Lima, 2001). Not being a static process, the formation of soils is subject to variations imposed by the environment, so that soils with similar geomorphological origin can be influenced by the environments in which they are inserted, promoting distinct chemical, physical and mineralogical characteristics (Moreira \& Vasconcelos, 2007; Vale Júnior et al., 2011).

Typically, in Central Amazon, soils are subdivided as present in two conditions: Firm Ground soils and Floodplain soils. In the Floodplain, mainly in the Solimões River, there is a predominance of soils that present natural drainage restrictions during part or all of the year, also known as hydromorphic soils (Lima, 2001; Teixeira et al., 2010). According to Teixeira et al. (2007), Gleisols represent up to $60 \%$ of the soils present in 
these conditions, around 3.940.00 hectares (acre), but others such as Fluvisols can be slightly representative. According to studies by Lima et al. (2006) and Guimarães et al. (2013), the soils of the Amazonian floodplains have a strong influence of the Andean and sub-Andean sediments, which generates agricultural potential, due to the predominantly eutrophic character, low relative contents of $\mathrm{Al}^{3+}$ and the presence of 2:1 minerals that give high capacity for cation exchange (CEC) (Lima et al., 2006; Silva et al., 2011; Guimarães et al., 2013).

The Firm Ground soils, those with no or low drainage restrictions, also known as Non-hydromorphic soils, are widely distributed in the Central Amazon, mainly Oxisols and Ultisols, which represent $41.05 \%$ and $32.94 \%$, respectively of all soils in the region (Rodrigues, 1996; Teixeira et al., 2010). In contrast to the poorly drained soils of the Floodplain, Firm Ground soils are generally more acidic, have greater activity and $\mathrm{Al}^{3+}$ contents, predominantly dystrophic and with low CEC due mainly to fewer active minerals such as kaolinite (Lima, 2001; Teixeira et al., 2010; Schaefer et al., 2017).

Brazilian soils are notably lacking in phosphorus (P), due to the characteristics of the source material and its strong interaction with soil components (Farias et al., 2016). The referred deficiency is found when the efficiency of $\mathrm{P}$ recovery, that is, what returns to plant production, is between 5 to $25 \%$ of what is applied (Yang et al., 2013). This fact justifies the large amounts of phosphate fertilizers used in Brazilian soils (Teles et al., 2017). Especially in the central portion of the Amazon, the processes of adsorption and availability of $P$ are more intense in relation to other regions of the country, mainly due to the climate conditions, marked by high rainfall and high temperature, as well as by the material of poor origin present (Novais et al., 2007; Melo \& Alleoni, 2009; Cravo et al., 2012).

The factors that influence the adsorption and availability of $\mathrm{P}$ can vary horizontally, according to the soil class, by specific formation processes, such as plinting and gleisation and can vary vertically in the soil profile, according to the layer compositions (Teixeira et al., 2018). Among the factors that can determine the behavior of $\mathrm{P}$ in the soil profile are the amount of organic matter, clay, $\mathrm{pH}$ and the levels and types of $\mathrm{Fe}$ and $\mathrm{Al}$ oxides. According to Gérard (2016), the quantitative and qualitative mineralogy and the quantities and types of clays are decisive in the $\mathrm{P}$ adsorption process.

Despite the differentiation between Hydromorphic and Non-hydromorphic soils, few studies have proposed to identify similarities or discrepancies between the first layers of soil $(0-0.05 ; 0.05-0.1 ; 0.1-0.2 \mathrm{~m})$ and the deeper layers $(>0.2 \mathrm{~m})$. In addition, the relationship between the chemical, physical and mineralogical changes imposed with the deepening of the soil profile can and influence the behavior of important nutrients in the soil, such as adsorption and availability of orthophosphate molecules $\left(\mathrm{H}_{2} \mathrm{PO}_{4}{ }^{-}\right.$and $\left.\mathrm{HPO}_{4}{ }^{2-}\right)$ in depth, and their behavioral differences on the surface and subsurface (Lima, 2001).

\section{Material and Methods}

\subsection{Description of Study Areas}

Two areas were selected at the limit of the Solimões Sedimentary Formation with the Alter do Chão formation in the Northwest portion of the State of Amazonas-Brazil. The first area is considered to be flooded in a good part of the year typical of Floodplain, given the profile of the highest water table in the rainiest months and the second area is configured as the highest typical of land areas in the state. Geodetic and climatological information is described in Figure 1 and Table 1. 


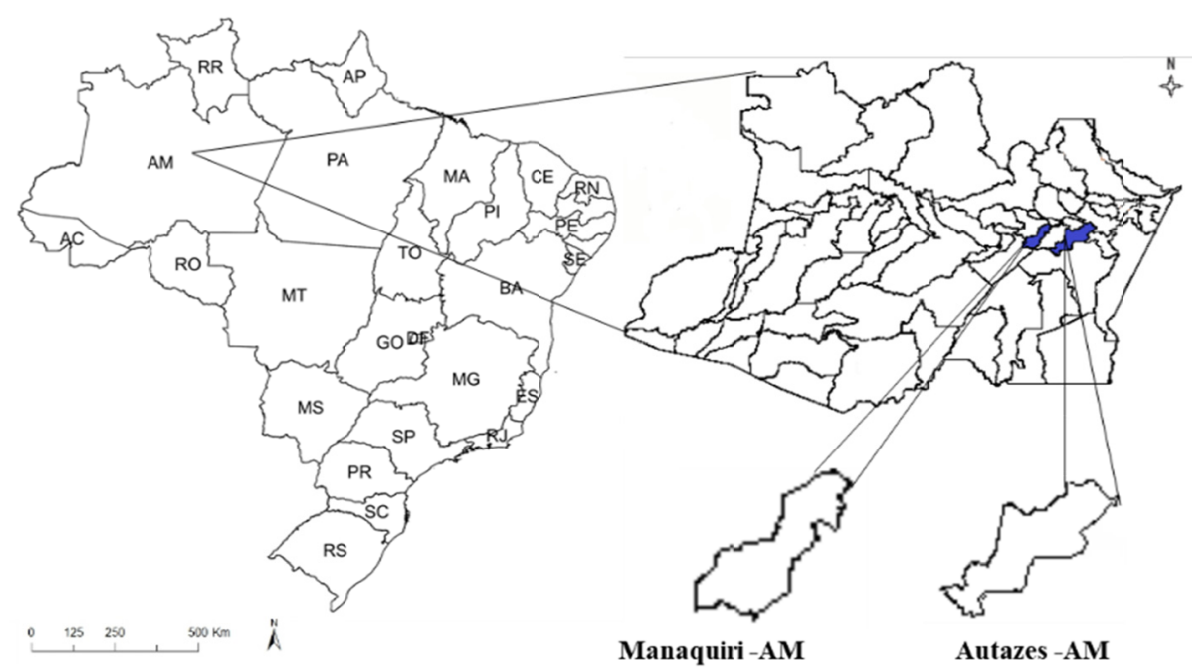

Figure 1. Location of study areas and soil collection

Source: João Dias, 2019.

Table 1. Geodesic characterization of the study areas (Source: João Dias, 2019)

\begin{tabular}{lllll}
\hline \multirow{2}{*}{ County } & \multicolumn{2}{c}{ Coordinates } & \multirow{2}{*}{ Location } & \multirow{2}{*}{ Altitude (m) } \\
\cline { 2 - 5 } & Latitude & Longitude & & \\
\hline Manaquiri-AM & $3^{\circ} 45^{\prime} 03.78^{\prime \prime} \mathrm{S}$ & $60^{\circ} 17^{\prime} 36.01^{\prime \prime} \mathrm{W}$ & BR-319 Km 101 & 22.0 \\
Autazes-AM & $3^{\circ} 29^{\prime} 14.38^{\prime \prime} \mathrm{S}$ & $59^{\circ} 50^{\prime} 47.89^{\prime \prime} \mathrm{W}$ & AM-254 Km 10.5 & 35.0 \\
\hline
\end{tabular}
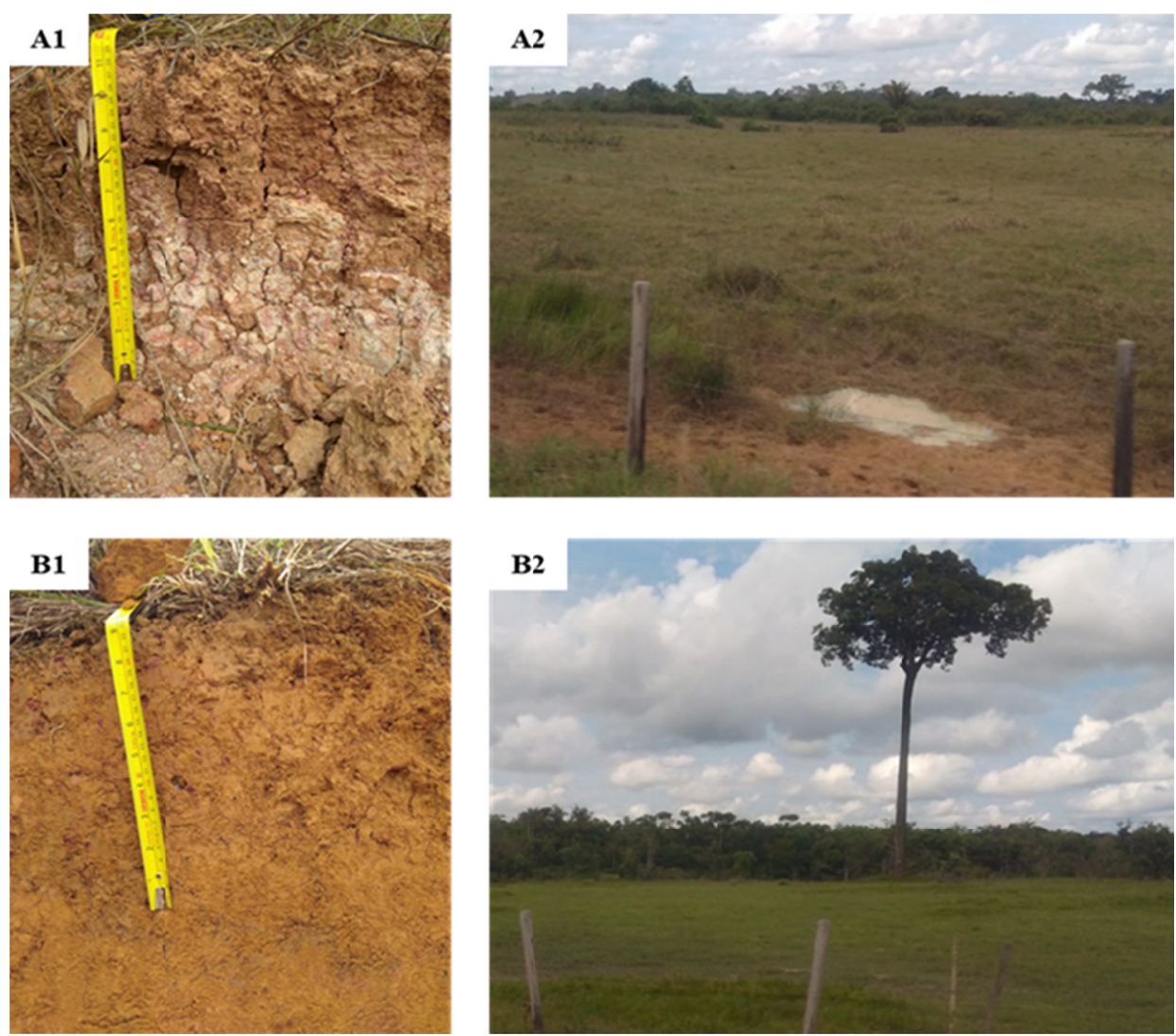

Figure 2. Gleysol Haplic Ta (A1); area associated with Gleysol (A2), Typical dystrophic Yellow Oxisol (B1) and area associated with Oxisol (B2) 


\subsection{Specific Procedures}

\subsubsection{Selection of Profiles and Soil Collections}

Soil profiles were selected with characteristics that met the following criteria: being modal, that is, with great relevance in the study area and in different environments, one poorly drained (Hydromorphic) and another with better drainage (Non-hydromorphic) (Figure 2). As this is a case study, the information does not accurately reflect the characteristics of other similar soil profiles, but it is possible to infer that under such conditions they are similar. The soils were classified according to the methodology of the Manual of Collection and Description of Soil in Field (Santos et al., 2015), Brazilian Soil Classification System (Santos et al., 2018) and Soil Maps of the Region.

For the study of adsorption, availability and soil characterization, five (05) collection depths were selected: $0.00-0.05 ; 0.05-0.1 ; 0.1-0.2 ; 0.2-0.4$ and $0.4-0.6 \mathrm{~m}$, in order to identify possible physical, chemical and mineralogical changes linked to phosphorus retention in the soil. For this purpose, the arable layer $(0-0.2 \mathrm{~m})$ was stratified in three levels: $0-0.05 \mathrm{~m}, 0.05-0.1 \mathrm{~m}$ and $0.1-0.2 \mathrm{~m}$ and the subsurface $(0.2-0.6)$ in two levels of identification: $0.2-0.4 \mathrm{~m}$ and 0.4-0.6 m. Under each profile, 10 subsamples were collected with approximately $100 \mathrm{~g}$ of soil in multipoint for each depth, in order to make up a composite sample $(1 \mathrm{~kg})$. In order to guarantee the suitability of the samples, the collection took place on a profile known to be not anthropically altered. After collection, the samples were properly identified and stored in a clean transparent bag. In an appropriate place, they were removed, homogenized, subjected to drying in the shade at room temperature until all moisture was removed. Afterwards, a $2.00 \mathrm{~mm}$ stainless steel sieve was passed to obtain the Air-Dried Fine Earth (ADFE).

\subsubsection{Soil Morphological and Physical Characterization}

The morphological characterization of the soils was carried out according to the criteria of the Manual of Collection and Description of Soil in Field (Santos et al., 2015) and the following aspects were evaluated: Color, Structure and the Dry, Damp and Wet Consistencies, being this last subdivided into Plasticity and Stickiness. The physical characterization was carried out according to the methodology of Embrapa (2017), being evaluated: Organic Matter and Granulometry, identifying the proportions of total sand, silt and clay. Based on the data obtained from the granulometry, the textural class of each studied soil depth was identified (USDA, 2011).

\subsubsection{Chemical Characterization of Soil}

The chemical characterization was realize according to the methodology of Embrapa (2017), being evaluated the following characteristics: Hydrogenionic Potential $(\mathrm{pH})$ in Water $\left(\mathrm{H}_{2} \mathrm{O}\right)$ and in Potassium Chloride $(\mathrm{KCl})$-Electrode method immersed in suspension in the ratio 1:2.5; Potential Acidity $\left(\mathrm{H}^{+}+\mathrm{Al}^{3+}\right)$ and Exchangeable Aluminum $\left(\mathrm{Al}^{3+}\right)$ - By means of determination by calcium acetate $\mathrm{Ca}\left(\mathrm{C}_{2} \mathrm{H}_{3} \mathrm{O}_{2}\right) 20.5 \mathrm{~mol} \mathrm{~L}^{-1}$ and $\mathrm{KCl}$ at $1 \mathrm{~mol} \mathrm{~L}^{-1}$, respectively and determination by titration with sodium hydroxide $\mathrm{NaOH} 0.025 \mathrm{~mol} \mathrm{~L}^{-1}$; Calcium $\left(\mathrm{Ca}^{2+}\right)$, Magnesium $\left(\mathrm{Mg}^{2+}\right)$ contents - were extracted by $\mathrm{KCl}$ solution at $1 \mathrm{~mol} \mathrm{~L}^{-1}$ and determined by atomic absorption spectrophotometry; Phosphorus (P), Potassium $\left(\mathrm{K}^{+}\right)$content-were extracted by Mehlich 1 solution $(0.05 \mathrm{M} \mathrm{HCl}+0.0125 \mathrm{M} \mathrm{HCl})$, $\mathrm{P}$ being determined by the blue molybdate method and by spectrophotometry $(\lambda=660 \mathrm{~nm})$ and $\mathrm{K}$ by flame photometer; Remaining Phosphorus (P-Rem) - was determined

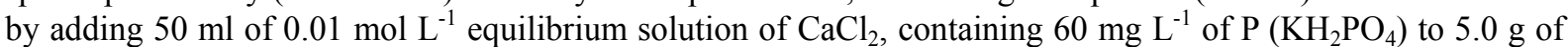
TDA. Afterwards, the samples will be stirred for 30 minutes at $150 \mathrm{rpm}$, leaving them to rest overnight, for about 16 hours. The determination was carried out in the solution was determined by the colorimetric method (Alvarez et al., 1999).

With the analytical laboratory data, the following attributes were estimated: Delta $\mathrm{pH}(\Delta \mathrm{pH})$ - Resulting from the difference between the $\mathrm{pH}$ values in $\mathrm{H}_{2} \mathrm{O}$ and $\mathrm{KCl}$, using the following formula: $\Delta \mathrm{pH}=\left(\mathrm{pH} \mathrm{H}_{2} \mathrm{O}-\mathrm{pH} \mathrm{KCl}\right)$, providing estimates of the net surface loads of soil minerals (Tan, 1982); Zero Charge Point (ZCP) - was estimated by the formula: $\mathrm{ZCP}=\left(2 \mathrm{pH} \mathrm{KCl}-\mathrm{pH} \mathrm{H} \mathrm{H}_{2} \mathrm{O}\right)$, according to the methodology of Uehara (1979); Sum of Bases (SB) - was estimated using the formula: $\mathrm{SB}=\mathrm{Ca}+\mathrm{Mg}+\mathrm{K}\left(\mathrm{cmol}_{\mathrm{c}} \mathrm{dm}^{-3}\right)$; Cation Exchange Capacity Effective ( $\mathrm{t}$ ) and potential $(\mathrm{T})$-Estimated using the formulas: $\mathrm{t}=\mathrm{SB}+\mathrm{Al}\left(\mathrm{cmol}_{\mathrm{c}} \mathrm{dm}^{-3}\right)$ and $\mathrm{T}=\mathrm{SB}+\left(\mathrm{H}^{+}+\mathrm{Al}^{3+}\right)$ $\left(\mathrm{cmol}_{\mathrm{c}} \mathrm{dm}^{-3}\right)$, respectively; Base Saturation (v\%) and Aluminum Saturation $(\mathrm{m} \%)$-The following were estimated by the formulas: $\mathrm{v}(\%)=(\mathrm{SB} / \mathrm{T}) \times 100$ and $\mathrm{m}(\%)=(\mathrm{Al} / \mathrm{t}) \times 100$, respectively. Clay Fraction Activity (CFA) - was estimated using the formula: CFA $=\mathrm{T} \times 1000 / \mathrm{g} \mathrm{kg}^{-1}$ of clay $\left(\mathrm{cmol}_{\mathrm{c}} \mathrm{dm}^{-3}\right)$.

\subsubsection{Mineralogical Characterization of Soil}

Mineralogical characterization was carried out according to Embrapa's methodology (2017) and other specific methodologies. From the clay fraction from the granulometry, the samples were centrifuged and placed on a glass slide to identify hematite $(\mathrm{Hm})$, goethite $(\mathrm{Gt})$, kaolinite $(\mathrm{Ct})$ and other existing minerals. The minerals were 
characterized in an X-ray diffractometer (XRD) with scanning speed of $1^{\circ} 2 \theta \mathrm{min}^{-1}$ using MiniFlex Rigaku II (20 $\mathrm{mA}, 30 \mathrm{kV}$ ), equipped with $\mathrm{Cu} \mathrm{K} \alpha$ radiation.

With the data obtained from diffractometry, the following attributes were analyzed: Identification of the peaks of the main minerals of Amazonian soils and the percentages of goethite (Gt) and hematite (Hm) were calculated by allocating the difference between the levels of dithionite iron $\left(\mathrm{Fe}_{\mathrm{d}}\right)$ and oxalate $\left(\mathrm{Fe}_{\mathrm{O}}\right)$ in relation to these oxides. Isomorphic substitution, or substitution of $\mathrm{Fe}$ for $\mathrm{Al}$, was estimated using the formula: $\left(\mathrm{Al}_{\mathrm{oFe}} / 27\right) /\left[\left(\mathrm{Al}_{\mathrm{oFe}} / 27\right)+\right.$ $\left.\left(\mathrm{Fe}_{\mathrm{c}} / 56\right)\right]$, where, $\mathrm{Al}_{\mathrm{oFe}}=\mathrm{Al}_{\mathrm{d}}-\mathrm{Al}_{\mathrm{o}}$ and $\mathrm{Fe}_{\mathrm{c}}=\mathrm{Fe}_{\mathrm{d}}-\mathrm{Fe}_{\mathrm{o}}$. The determinations of Iron $\left(\mathrm{Fe}_{\mathrm{d}}\right)$ and Aluminum $\left(\mathrm{Al}_{\mathrm{d}}\right)$ oxides in crystalline form, samples of TDA will be subjected to extraction in sodium dithionite-citrate-bicarbonate (DCB) solution (Mehra \& Jackson, 1960). of the low crystallinity oxides for Iron $\left(\mathrm{Fe}_{\mathrm{o}}\right)$ and Aluminum $\left(\mathrm{Al}_{\mathrm{d}}\right)$, the extractions will be carried out with ammonium oxalate solution at $0.2 \mathrm{~mol} \mathrm{~L}^{-1}$ at $\mathrm{pH}$ 3.0, in the dark (Schwertmann, 1964). Starting from solubilized iron oxides will be determined by absorbance in the spectrophotometer (Micronal ${ }^{\circledR}$ Spectophotometer model B-580) at a wavelength of $518 \mathrm{~nm}$, while the aluminum oxides at a wavelength of $555 \mathrm{~nm}$. Aluminum Oxalate and Dithionite $\left(\mathrm{Al}_{\mathrm{o}} / \mathrm{Al}_{\mathrm{d}}\right)$ and Iron Oxalate and Dithionite $\left(\mathrm{Fe}_{\mathrm{o}} / \mathrm{Fe}_{\mathrm{d}}\right)$ ratio.

\section{Results and Discussion}

\subsection{Morphological and Physical Attributes}

In the morphological attributes, there was a gradual color change with the deepening of the section of the studied soils (YOd and GHd) (Table 2). Although there is this change, the reasons were different. The soil color offers a range of information regarding drainage, iron minerals and organic matter (Spanner et al., 2014), which may infer that the processes that affect the availability and retention of phosphorus (P) may be different in the layers stratified.

In the Typical Yellow Dystrophic Oxisol (YOd), the alteration occurs due to the decrease of organic matter in the direction of the subsurface horizons, changing the color from Yellow-brown (10 YR 5/4) to Yellow (10 YR 8/8), evidencing the prevalence of the iron mineral goethite $(\mathrm{FeOOH})$ and indicating good drainage (Spanner et al., 2014). In the Dystrophic Gleysol Haplic (GHd), the color is changed from 5 YR 5/8 (red-brown) to 5 YR 8/2 (gray-white), due to the process of gleization, in which there is chemical and mineral reduction of $\mathrm{Fe}$ in the absence of oxygen $\left(\mathrm{O}_{2}\right)$ for a certain period and, consequently, its exit from the soil section (Schaefer et al., 2017).

In the physical attributes, the sand content (coarse + fine) represents less than $10 \%$ of the granulometry of the observed soils. The behavior of decreasing sand in depth was also observed by other authors in Amazonian soils (Macedo, 2009; Guimarães et al., 2013) (Figure 3A). In both soils, the silt contents decreased up to $0.2 \mathrm{~m}$ and slightly stabilized in depth $(>0.2 \mathrm{~m})$ (Figure 3B). It was observed that while in the Latosol the silt contents reach a maximum of $25 \%$ of the granulometry, in the Gleysols it reaches close to $50 \%$. In his characterization work, Lima (2001) observed the same behavior in the Gleysols, which are mostly silty and probably related to the low pedogenesis of hydromorphic environments in relation to those on dry land. 
Table 2. Morphological characteristics stratified in layers of a Dystrophic Yellow Oxisol (YOd) and a Gleysol Haplic Ta (GHd) in Central Amazon

\begin{tabular}{|c|c|c|c|c|c|c|}
\hline \multicolumn{7}{|c|}{ Typical Dystrophic Yellow Oxisol (YOd) } \\
\hline Depth & & $0-5 \mathrm{~cm}$ & $5-10 \mathrm{~cm}$ & $10-20 \mathrm{~cm}$ & $20-40 \mathrm{~cm}$ & $40-60 \mathrm{~cm}$ \\
\hline \multicolumn{7}{|l|}{ Samples ${ }^{(1)}$} \\
\hline Color $^{(2)}$ & & 10 YR 5/4 & 10 YR $6 / 6$ & 10 YR $7 / 8$ & 10 YR $7 / 8$ & $10 \mathrm{YR} 8 / 8$ \\
\hline Structure $^{(3)}$ & & $\mathrm{st} / \mathrm{gn} / \mathrm{ag} / \mathrm{sb} / \mathrm{sm}$ & $\mathrm{md} / \mathrm{gn} / \mathrm{ag} / \mathrm{sb} / \mathrm{sm} / \mathrm{av}$ & $\mathrm{md} / \mathrm{gn} / \mathrm{ag} / \mathrm{sb} / \mathrm{sm} / \mathrm{av}$ & $\mathrm{wk} / \mathrm{gn} / \mathrm{ag} / \mathrm{sb} / \mathrm{sm} / \mathrm{av}$ & $\mathrm{wk} / \mathrm{gn} / \mathrm{ag} / \mathrm{sb} / \mathrm{sm} / \mathrm{av}$ \\
\hline Dry consistenc & & Slightly Hard & Slightly Hard & Soft & Soft & Soft \\
\hline Wet consistenc & & Firm & Friable & Friable & Friable & Friable \\
\hline \multirow{2}{*}{ Wet consist. } & Plasticity & Slightly Plast. & Plastic & Plastic & Plastic & Plastic \\
\hline & Stickiness & Slightly Sticky & Slightly Sticky & Slightly Sticky & Sticky & Sticky \\
\hline \multicolumn{7}{|c|}{ Dystrophic Gleysol Haplic Ta (GHd) } \\
\hline \multicolumn{2}{|l|}{ Depth } & $0-5 \mathrm{~cm}$ & $5-10 \mathrm{~cm}$ & $10-20 \mathrm{~cm}$ & $20-40 \mathrm{~cm}$ & $40-60 \mathrm{~cm}$ \\
\hline \multicolumn{7}{|l|}{ Samples } \\
\hline \multicolumn{2}{|l|}{ Color } & 5 YR 5/8 & 5 YR $6 / 8$ & $5 \mathrm{YR} 7 / 8$ & $5 \mathrm{YR} 7 / 4$ & $5 \mathrm{YR} 8 / 2$ \\
\hline \multicolumn{2}{|l|}{ Structure } & $\mathrm{md} / \mathrm{gn} / \mathrm{ag} / \mathrm{sb} / \mathrm{sm}$ & $\mathrm{wk} / \mathrm{gn} / \mathrm{ag} / \mathrm{sb} / \mathrm{sm} / \mathrm{av}$ & $\mathrm{wk} / \mathrm{gn} / \mathrm{sb} / \mathrm{sm} / \mathrm{av}$ & $\mathrm{wk} / \mathrm{gn} / \mathrm{sb} / \mathrm{sm} / \mathrm{av}$ & $\mathrm{wk} / \mathrm{gn} / \mathrm{sb} / \mathrm{sm} / \mathrm{av}$ \\
\hline \multicolumn{2}{|c|}{ Dry consistency } & Slightly Hard & Soft & Soft & Soft & Soft \\
\hline \multicolumn{2}{|c|}{ Wet consistency } & Friable & Very Friable & Very Friable & Very Friable & Very Friable \\
\hline \multirow{2}{*}{ Wet consist. } & Plasticity & Plastic & Plastic & Plastic & Plastic & Plastic \\
\hline & Stickiness & Sticky & Sticky & Sticky & Sticky & Very Sticky \\
\hline
\end{tabular}

Note.${ }^{(1)}$ Air Dry Samples; ${ }^{(2)}$ Soil color according to Munsell; ${ }^{(3)}$ Structure: Strong (st), Weak (wk), Granular (gn), Angular (ag), Subangular (sb), Small (sm), Average (av).

Regarding the clay content, there was an increasing increase in the first $20 \mathrm{~cm}$ in both soils, but with higher levels for the Oxisol, due to the high weathering in its pedogenetic process (Schaefer et al., 2017) (Figure 3C). According to Novais et al. (2007), the clay content of a soil, as well as the type of clay present has a strong relationship with negatively charged orthophosphate ions and according to studies by Falcão and Silva (2004) in some Amazonian soils, the correlation between clay and phosphorus adsorption capacity (P) have high affinity. According to Bahia Filho et al. (1983), the clay and $\mathrm{P}$ adsorption ratio is not always synergistic, and may vary with its characteristic.

In both soils there is a gradual decrease in the levels of organic matter in the soil (OMS). More intensely in the Yellow Oxisol (YO) (Figure 4). In practice, the decrease in the OMS of the lower soil layers is directly related to the modification of the YOd color and acts in a similar way in the Gleysol Haplic (GHd) and this is due to the decrease of organic sources in depth, promoting structural changes and soil chemicals (Bunemann, 2015). Organic matter can act in different ways in the adsorption of $\mathrm{P}$ in the soil, and can elevate the process, through cation bridges with $\mathrm{Fe}$ and $\mathrm{Al}$, for example, or it can act directly in blocking the adsorption sites present on the surface of clays and oxides (Aquino, 2004; Yan et al., 2016). 


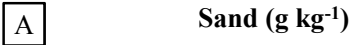

$\begin{array}{lllllllll}30 & 40 & 50 & 60 & 70 & 80 & 90 & 100\end{array}$

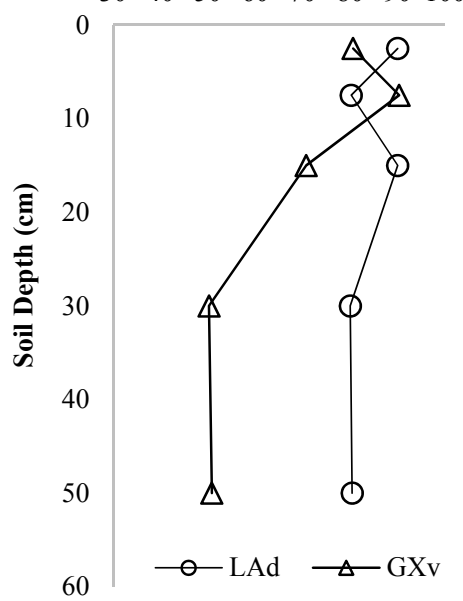

Clay $\left(\mathrm{g} \mathrm{kg}^{-1}\right)$
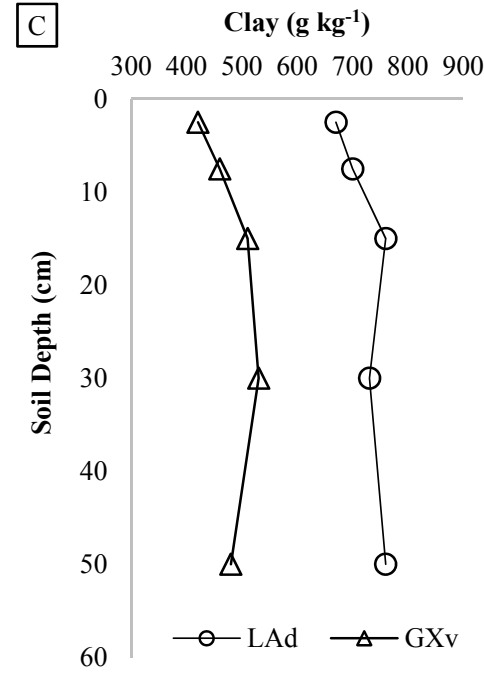

B Silt $\left(\mathrm{g} \mathrm{kg}^{-1}\right)$

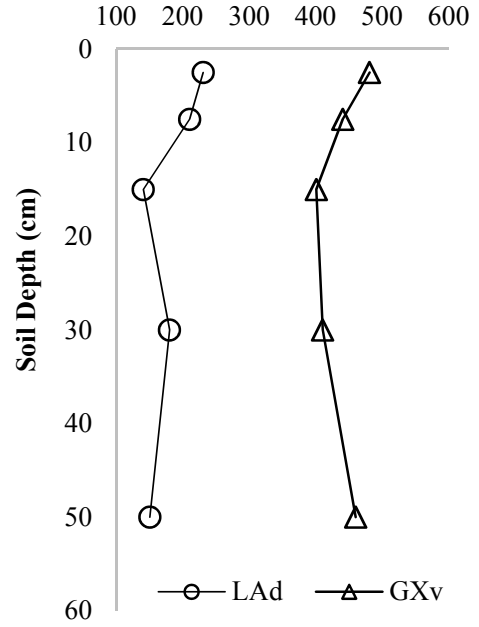

$\mathrm{D}$

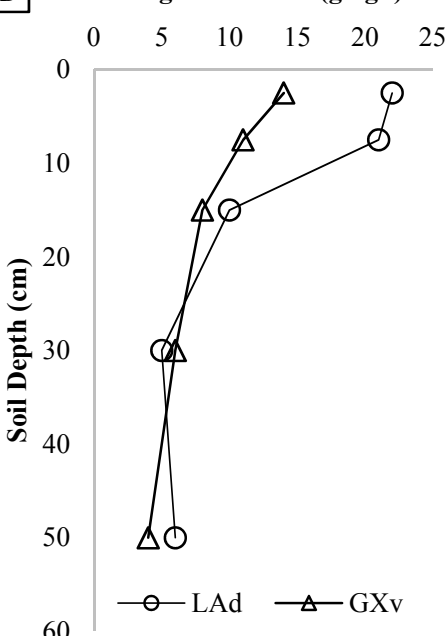

Figure 3. Sand (A) Silt (B), Clay (C) and Organic matter content (D) contents of a Hydromorphic (GHd) and Non-hydromorphic (YOd) soil in the Central Amazon

\subsection{Chemical Attributes}

The $\mathrm{pH}$ in water $\left(\mathrm{H}_{2} \mathrm{O}\right)$ and in potassium chloride $(\mathrm{KCl})$ showed an increasing trend in both soils studied with depth (Figures 4A and 4B). Despite the water $\mathrm{pH}$ of soils with values between 5.1 and 5.5 , the $\mathrm{pH}$ normally found for soils in the Amazon is below 4.5 in most cases, as observed by Lima (2001), Falcão and Silva (2004), and Oliveira et al. (2019). The soil $\mathrm{pH}$ can have a double influence on the availability and adsorption of phosphorus (P) in the soil. On the one hand, the elevation of the $\mathrm{pH}$ reduces the formation of stable precipitates, mainly with $\mathrm{Fe}$ and $\mathrm{Al}$. On the other hand, the variable charges of the minerals become more negative, promoting the repulsion of the phosphate molecules and the surface, consequently reducing the processes of fixation (Barrow, 1985; Cunha et al., 2014).

The values obtained from $\Delta \mathrm{pH}$ between -1.1 and -1.3 , determined from the difference between $\mathrm{pH}(\mathrm{KCl})-\mathrm{pH}$ $\left(\mathrm{H}_{2} \mathrm{O}\right)$, indicate a negative net surface charge of soil minerals, which in summary means that the ability to exchange soil cations (CEC) surpasses the ability to exchange anions (CEA), such as $\mathrm{H}_{2} \mathrm{PO}_{4^{-}}$and $\mathrm{HPO}_{4}{ }^{2-}$, at natural $\mathrm{pH}$ in these soils (Cunha et al., 2014) (Figure 4C). The values found in this work corroborate those found by Ferreira and Botelho (1999), between -1.1 and -1.2 in 12 soils in Central Amazonia. According to Kiehl (1979), the presence of negative $\Delta \mathrm{pH}$ represents the predominance of silicate clays to the detriment of oxides and hydroxides. 

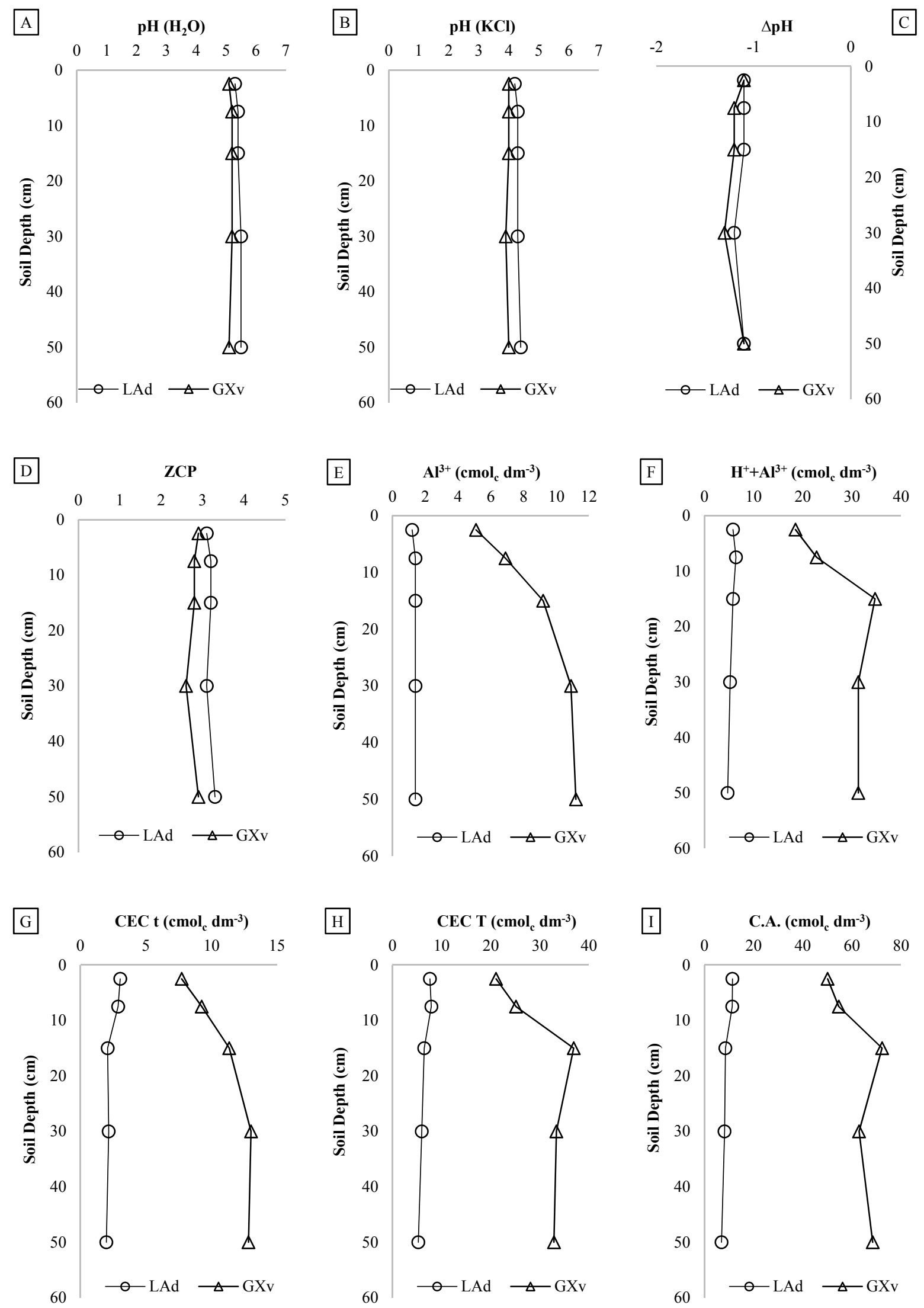

Figure 4. $\mathrm{pH}$ contents in water (A) and $\mathrm{KCl}(\mathrm{B})$, Delta $\mathrm{pH}$ (C), Zero Charge Point (D), Exchangeable Aluminum

(E), Potential Acidity (F), Effective Cation Exchange Capacity (G) and Potential (H), Clay Activity (I) of a Hydromorphic (GHd) and Non-hydromorphic (YOd) soil in the Central Amazon 
Like $\Delta \mathrm{pH}$, the Zero Charge Point (ZCP) was similar between the studied soils (Figure 4D). ZCP is an important factor in determining the variable loads on the surface of minerals. According to the estimated ZCP, lower than the obtained values of $\mathrm{pH}\left(\mathrm{H}_{2} \mathrm{O}\right)$ indicate that there is a strong negative charge exposed on minerals, increasing the possibilities of P adsorption in the soil (Baldotto \& Velloso, 2014). In the Amazon Region, ZCP among minerals is distinct; while the kaolinite $\mathrm{ZCP}$ is around $\mathrm{pH} 3.5-4.0$, Fe minerals (Hematite and Goethite) between 8.0-8.5, $\mathrm{Al}^{3+}$ minerals (gibbsite) between 6.0-6.5 and the OMS below 2.0 (J. L. I. Demattê \& J. A. M. Demattê, 1993; Alleoni, 2017). In general, the ZCP values tend to increase in depth, due to the decrease in soil organic matter, increasing the adsorption of $\mathrm{P}$ (Alleoni, 2017).

The levels of exchangeable aluminum $\left(\mathrm{Al}^{3+}\right)$ were practically constant in the Yellow Oxisol (YOd) and less high in relation to the Gleysol Haplic (GHd) (Figure 4E). Despite this, $\mathrm{Al}^{3+}$ levels above $1.0 \mathrm{cmol}_{\mathrm{c}} \mathrm{dm}^{-3}$ are considered high in Amazonian soils by Cravo et al. (2007). When studying ten Yellow Oxisol in the Central Amazon, Barbosa (2017) verified $\mathrm{Al}^{3+}$ levels between 0.80 and $1.80 \mathrm{cmol}_{\mathrm{c}} \mathrm{dm}^{-3}$, corroborating those found in this work. In GHd, the levels of $\mathrm{Al}^{3+}$ differ from those found in Gleysols of Amazon Guimarães et al. (2013), who found a maximum of $4.71 \mathrm{cmol}_{\mathrm{c}} \mathrm{dm}^{-3}$. In Plinthosols, soils that undergo some hydromorphization process, Lima (2001) verified levels above $10 \mathrm{cmol}_{\mathrm{c}} \mathrm{dm}^{-3}$. In general, soils with higher exchangeable $\mathrm{Al}^{3+}$ are more likely to form precipitates of free $\mathrm{Al}$ cations with $\mathrm{P}\left(\mathrm{AlPO}_{4}\right)$, decreasing availability (Gatiboni et al., 2013).
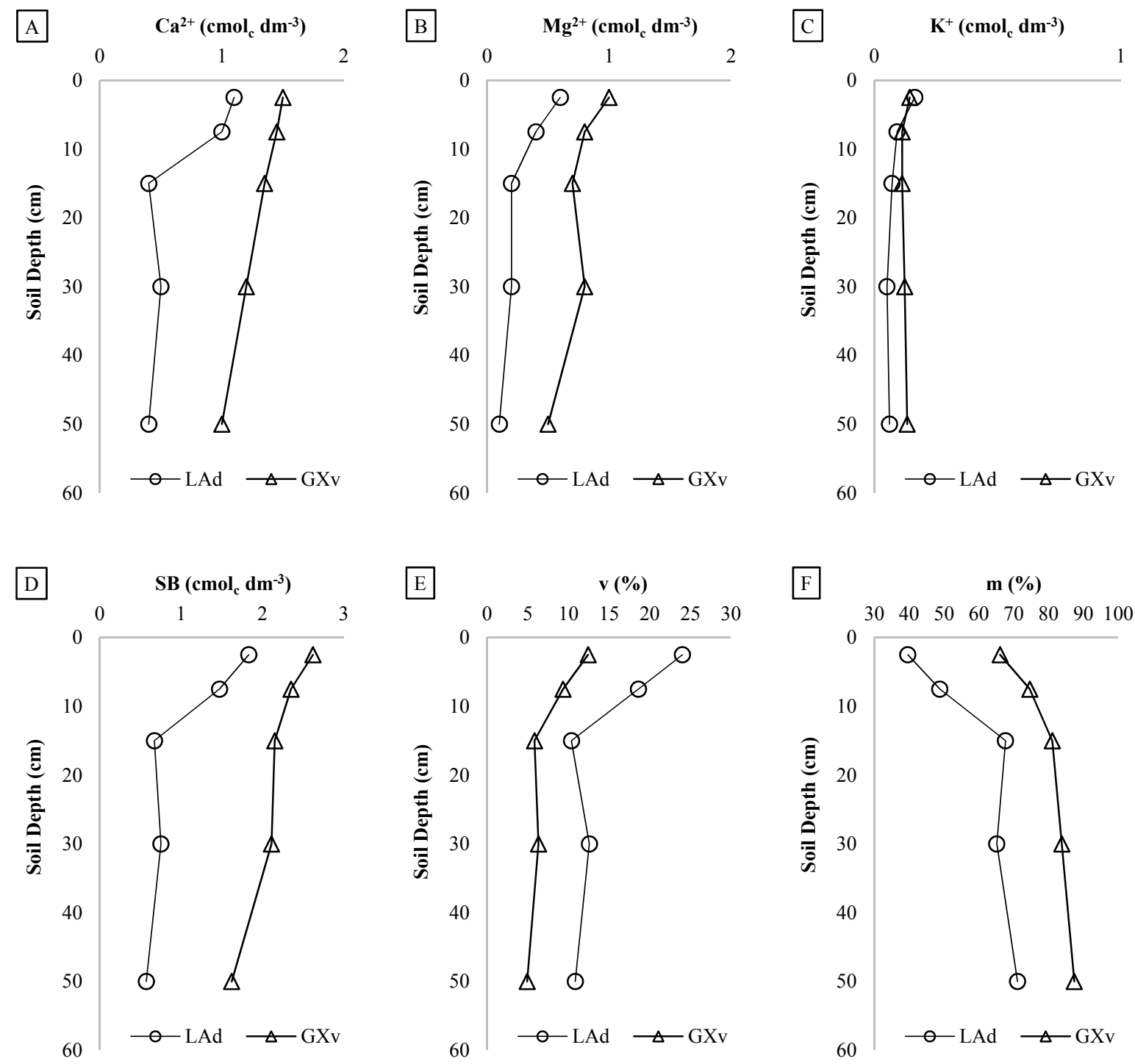

Figure 5. Calcium (A), Magnesium (B), Potassium (C), Sum of Bases (D), Saturation by Bases (E) and Aluminum Saturation (F) of a Hydromorphic (GHv) and Non-hydromorphic (YOd) in Central Amazon 
Potential acidity $\left(\mathrm{H}^{+}+\mathrm{Al}^{3+}\right)$ varied from 4.7 to $6.4 \mathrm{cmol}_{\mathrm{c}} \mathrm{dm}^{-3}$ in the Oxisol, decreasing in depth and from 18.5 to $34.7 \mathrm{cmol}_{\mathrm{c}} \mathrm{dm}^{-3}$ in the Gleysol, increasing in depth (Figure 4F). According to CFSFMG (1999), $\mathrm{H}^{+}+\mathrm{Al}^{3+}$ levels above $9.0 \mathrm{cmol}_{\mathrm{c}} \mathrm{dm}^{-3}$ are considered to be very high and reflect a high soil buffer power (Husni et al., 1995). According to Guilherme et al. (2000), in Gleysols, the high values of $\mathrm{H}^{+}+\mathrm{Al}^{3+}$ are directly related to the increase in $\mathrm{P}$ adsorption, as there is an increase in $\mathrm{Fe}^{2+}$ retention and consequent generation of negative charges, which after drainage, can be oxidized, leading to greater adsorption.

Both effective CEC ( $t$ ) and potential CEC (T) were higher in Gleysol Haplic than in Yellow Oxisol and with a tendency to increase in depth (Figures $4 \mathrm{G}$ and $4 \mathrm{H}$ ). The higher CEC values in Gleysols indicates the presence of clay minerals with high activity, such as 2:1 minerals, giving these soils a high CEC (Guimarães et al., 2013). In general, in Oxisols, CEC of less than $10 \mathrm{cmol}_{\mathrm{c}} \mathrm{dm}^{-3}$ are verified, as those verified by Tucci (1991) and Falcão e Silva (2004) in Central Amazon. In summary, the increase in CEC seems to have little influence on the adsorption of phosphorus in the soil, given that the orthophosphate molecules are negatively charged, generating less adherence on the negatively charged colloidal surfaces (Novais et al., 2007). In relation to the clay activity (CA), while in the Oxisol it presents low activity in all depths $\left(<27 \mathrm{cmol}_{\mathrm{c}} \mathrm{dm}^{-3}\right)$, in the Gleysol the activity is high $\left(>27 \mathrm{cmol}_{\mathrm{c}} \mathrm{dm}^{-3}\right)$ in all depths (Santos, 2018). In the Amazon, in a Typical Yellow Dystrophic Oxisol, Lima (2001) observed clay activity values of $21.04 \mathrm{cmol}_{\mathrm{c}} \mathrm{dm}^{-3}$ in surface, decreasing below $7.00 \mathrm{cmol}_{\mathrm{c}} \mathrm{dm}^{-3}$ in depth, but corroborating the predominance of low-activity clays in Oxisols (Figure 4I). This same author, when analyzing a eutrophic Gleysol Haplic Ta, found a maximum above $74.06 \mathrm{cmol}_{c} \mathrm{dm}^{-3}$ in the upper layers, also corroborating the results obtained here.

Although the Gleysol Haplic has higher levels of nutrients $\left(\mathrm{Ca}^{2+}, \mathrm{Mg}^{2+}\right.$ and $\left.\mathrm{K}^{+}\right)$than the Yellow Oxisol, the levels tend to decrease in depth in both soils, due to the decrease in organic matter (Figures 5A, 5B and 5C). According to the classification of nutrients by Cravo et al. (2007), the levels of $\mathrm{Ca}^{2+}, \mathrm{Mg}^{2+}$ and $\mathrm{K}^{+}$found in both soils are classified as low, an inherent characteristic of the formation and leaching of nutrients in the Amazon. The slightly higher levels of $\mathrm{Ca}^{2+}, \mathrm{Mg}^{2+}$ and $\mathrm{K}^{+}$in Gleysol may be related to materials recently deposited or with less exposure to weathering (Rodrigues, 1996).

\subsection{Mineralogical Attributes}

For the Yellow Oxisol (YOd), the levels of Aluminum Oxalate (poorly crystallized) varied from $1.02 \mathrm{~g} \mathrm{~kg}^{-1}$ in surface $(0-5 \mathrm{~cm})$ to $0.58 \mathrm{~g} \mathrm{~kg}^{-1}$ in subsurface $(40-60 \mathrm{~cm})$, while in Gleysol Haplic (GHd) it varied from 2.13 to $0.62 \mathrm{~g} \mathrm{~kg}^{-1}$ under the same conditions. Although the same behavior was observed by Lima (2001) for similar soils and in different strata, the levels found were lower than those observed by him. Similar behavior was observed for the levels of Iron Oxalate, for the YOd from 2.21 to $0.42 \mathrm{~g} \mathrm{~kg}^{-1}$ and for the $\mathrm{GHv}$ from 9.03 to $0.62 \mathrm{~g}$ $\mathrm{kg}^{-1}$, respectively on surface and subsurface (Figures 6A and 6D). The reduction in the levels of poorly crystallized minerals is possibly due to the effect of inhibiting organic matter in the upper layers and specifically in the Gleysol, the periods of flooding contribute more strongly to the non-crystallization of the forms of $\mathrm{Al}$ and Fe (Schwertmann, 1966). In ten Oxisols in the Central Amazon, Barbosa (2017) found poorly crystallized Fe contents between 0.14 and $0.31 \mathrm{~g} \mathrm{~kg}^{-1}$, lower than those observed in this study.

In the amorphous forms of Iron and Aluminum (FeDit and AlDit), behavior similar to that of bad crystallized was obtained (Figures 6B and 6E). In GHd, there is a strong reduction of $\mathrm{Fe}$ and $\mathrm{Al}$ minerals from the surface to the subsurface, from 22.9 to $5.8 \mathrm{~g} \mathrm{~kg}^{-1}$ and from 5.4 to $1.8 \mathrm{~g} \mathrm{~kg}^{-1}$, respectively. In contrast, both levels were high in subsurface in the YOd. The subsurface conditions found in the Oxisol, such as low organic matter and drained environment, can influence the aging of iron oxides, while in the subsurface conditions of the Gleysol, the reduced environment over prolonged periods changes the structure of minerals, removing them from the system and / or hindering its perfect crystallization (Schwertmann, 1966; Kämpf \& Curi, 2000; Lima, 2001).

Both in the Aloxalate/Alditionite ratio and in the Feoxalate/Feditionite ratio, the Gleysol Haplic presents a greater amount of poorly crystallized minerals in relation to the Yellow Latosol, due to its redox condition (Figures 6C and 6F). In general, greater relations on the surface of both soils were already expected, considering that the presence of organic matter on the surface makes it difficult to crystallize the oxides in relation to the subsurface (Lima, 2001). The reduction of amorphous and poorly crystallized minerals may have a direct influence on phosphorus adsorption, since according to Gerard (2016), the sorption capacity of Fe and Al oxides increases proportionally with the increase of their specific surface, creating more points of attachment with $\mathrm{H}_{2} \mathrm{PO}_{4}{ }^{-}$and $\mathrm{HPO}_{4}{ }^{2-}$. 

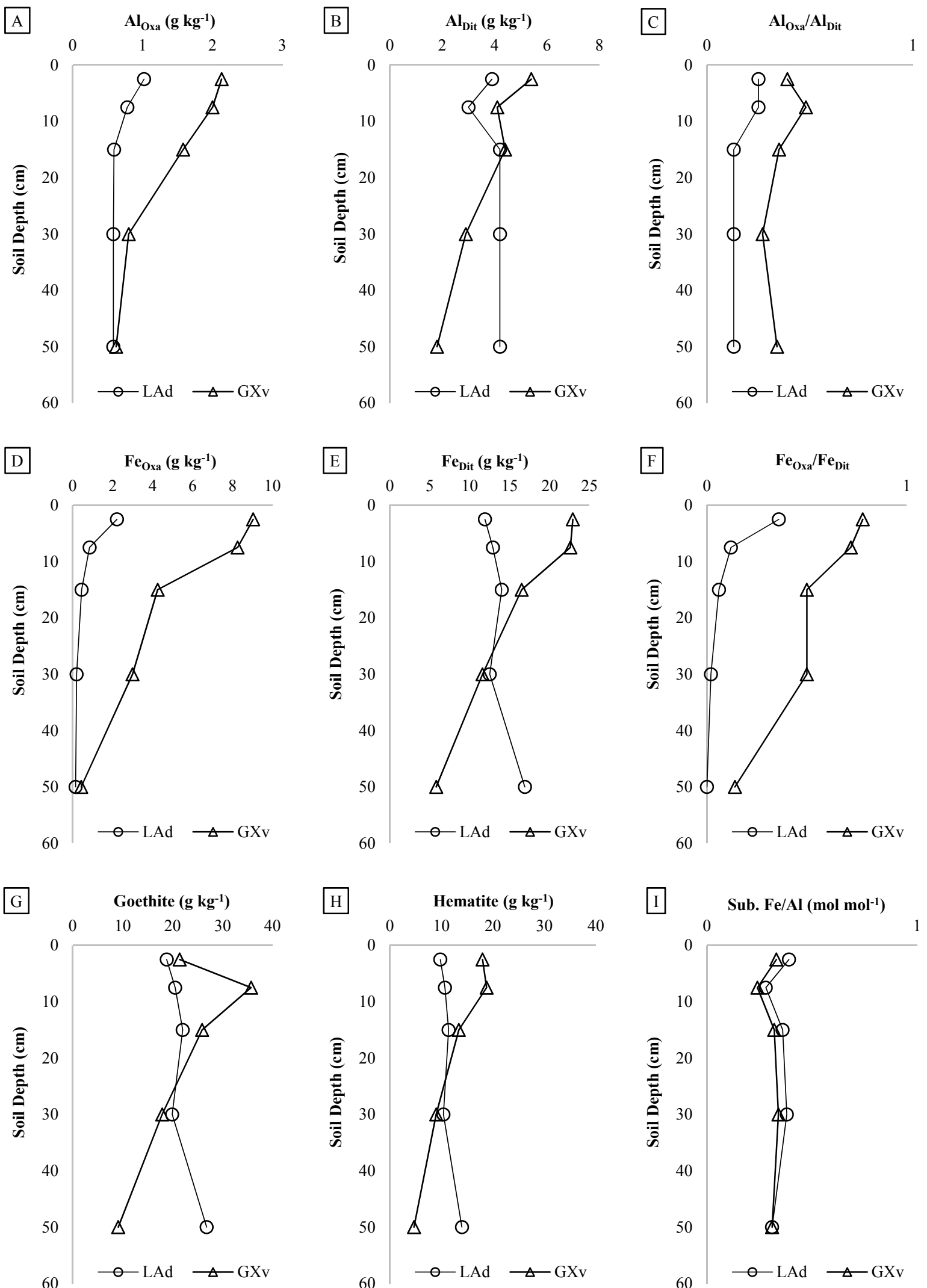

Figure 6. Aluminum Oxalate (A), Aluminum Dithionite (B), Aluminum Oxalate: Aluminum Dithionite (C), Fero Oxalate (D), Iron Dithionite (E), Iron Oxalate: Iron Dithionite (F), Goethite (G) ), Hematite (H), Isomorphic Replacement of Iron with Aluminum (I) of a Hydromorphic (GHd) and

Non-hydromorphic (YOd) in Central Amazon 

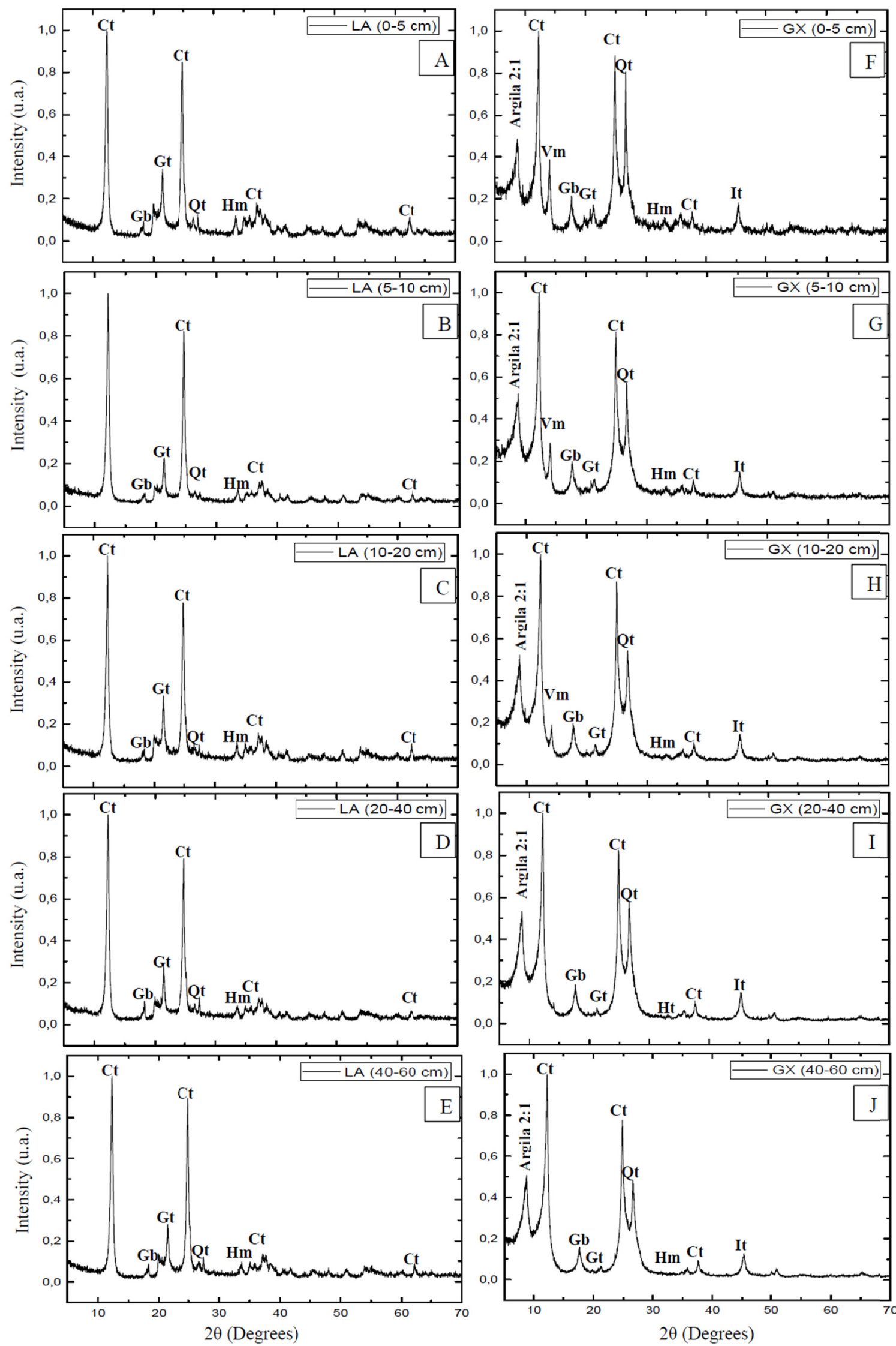

Figure 7. X-Ray Diffractometry of a Hydromorphic (GHd) and Non-hydromorphic (YOd) soil in the Central Amazon at depths 0-5 cm (AF), 5-10 cm (BG), 10-20 cm (CH), 20-40 cm (DI) and 40-60 cm (EJ) 
Proportionally to the levels of $\mathrm{Fe}$ ditionite and oxalate, the behavior of the levels of Goethite- $\mathrm{Gt}(\mathrm{FeOOH})$ and Hematite $-\mathrm{Hm}\left(\mathrm{Fe}_{3} \mathrm{O}_{2}\right)$ were similar. In the Yellow Oxisol, there was an increase in depth from 18.8 to $26.8 \mathrm{~g}$ $\mathrm{kg}^{-1}$ of Gt and from 9.8 to $14.8 \mathrm{~g} \mathrm{~kg}^{-1}$ of Hm, respectively on the surface $(0-5 \mathrm{~cm})$ for subsurface $(40-60 \mathrm{~cm})$. Under the same conditions, in the Gleysol Haplic, there was a decrease from 21.4 to $9.1 \mathrm{~g} \mathrm{~kg}^{-1}$ of Gt and from 18.5 to $4.7 \mathrm{~g} \mathrm{~kg}^{-1}$ of $\mathrm{Hm}$ (Figures $6 \mathrm{G}$ and $6 \mathrm{H}$ ). For soils in the central Amazon, Barbosa (2017) observed levels of Goethite between 3.62 and $59.74 \mathrm{~g} \mathrm{~kg}^{-1}$ and Hematite between 3.35 and $53.37 \mathrm{~g} \mathrm{~kg}^{-1}$. In practice, the decrease in the content of these iron oxides in the Gleisols can be confirmed by the gradual change in the color of the layers. In general, the values of isomorphic substitution of Fe for $\mathrm{Al}$ were similar between Gleysol and Oxisol, varying from 0.39 to 0.31 and between 0.33 and $0.24 \mathrm{~mol} \mathrm{~mol}^{-1}$ (Figure 6I). The observed values were higher than those observed by Moller (1991), Lima (2001) and similar to those obtained by Barbosa (2017) in Amazonian soils. The substitutions in the Latosol and mainly in the surface are higher than in the Gleysol, which is probably related to the greater mobility of Fe than in that one (Fitzpatrick \& Schwertmann, 1982).

Qualitatively, observing the diffractograms of the clay fraction, it is possible to observe that there are peaks very similar to the five studied depths of the Yellow Latosol, where there is a predominance of minerals such as Kaolinite, Goethite, Hematite, Quartz and Gibbisite traces (Figures 7A, 7B, 7C, 7D and 7E). Peak minerals from Kaolin, Goethite, Hematite, Quartz, Vermiculite, traces of Gibbite, Ilite and other type 2:1 mineral (Mica, Smectite) (Figures 7F, 7G, 7H, 7I and 7J) were observed in the Gleysol Haplic. According to Teixeira et al. (2010), in Oxisols in the Amazon, there is a predominance of clay minerals 1:1, such as kaolinite and iron oxides (Goethite and Hematite). Analyzing a Toposequence in the Central Amazon, Lima et al. (2006) verified similar minerals in soils with some degree of hydromorphism, not observing significant differences from the minerals found on the surface or subsurface of these soils.

The predominance of kaolinite in the clay fraction has been reported in other studies on Amazonian soils (Lima et al., 2006; Garcia et al., 2013; Barbosa, 2017). According to Marques et al. (2010), this kaolinitic nature is due to a tertiary sedimentary lithology, which gives long periods of chemical and physical weathering, making them abundant and stable in Amazonian soils. According to Sombroek (1966), kaolinites can compose up to 80\% of the minerals of the clay fraction, however, according to Gérard (2016), kaolinites can present lower phosphorus sorption rates than other minerals due to their smaller specific surface and the low ZCP. In contrast, Fe minerals common in weathered tropical soils, as they have a higher specific surface and a higher ZCP, sorption tends to be higher. According to Fox and Sedarle (1978), the sorption of P follows a sequence in which the amorphous oxides of $\mathrm{Fe}$ and $\mathrm{Al}$ are preferred $>$ Crystalline oxides of $\mathrm{Fe}$ and $\mathrm{Al}$ and Clay 1:1.

\section{Conclusions}

In both soils, the levels of sand and silt remain stable with the deepening of the soil profile. The contents of silt are higher in Hydromorphic soil. Clay contents increase in depth and are higher in Non-hydromorphic soil. In both soils, the levels of soil organic matter $(\mathrm{OM})$ decrease dramatically in depth. The $\mathrm{pH}$ in water $\left(\mathrm{pHH}_{2} \mathrm{O}\right)$ and in potassium chloride $(\mathrm{KCl})$, delta $\mathrm{pH}(\Delta \mathrm{pH})$ and zero charge point $(\mathrm{ZCP})$ are similar between Hydromorphic and Non-hydromorphic soil and show a tendency to increase in depth. Exchangeable aluminum $\left(\mathrm{Al}^{3+}\right)$, potential acidity $\left(\mathrm{H}^{+}+\mathrm{Al}^{3+}\right)$, effective cation exchange capacity $(\mathrm{t})$ and potential $(\mathrm{T})$ and clay activity (CA) are similar on the surface $(<20 \mathrm{~cm})$ and subsurface $(>20 \mathrm{~cm})$ on Non-hydromorphic soil. In hydromorphic soil, these attributes increase on the surface $(<20 \mathrm{~cm})$ and remain stable on the subsurface $(>20 \mathrm{~cm})$.

The levels of calcium $\left(\mathrm{Ca}^{2+}\right)$, magnesium $\left(\mathrm{Mg}^{2+}\right)$, potassium $\left(\mathrm{K}^{+}\right)$, sum of bases $(\mathrm{SB})$ and saturation by bases $(\mathrm{v} \%)$ are reduced with the deepening of the profile in the Hydromorphic soil and in the Non-hydromorphic soil. Hydromorphic soil has higher relative contents of these attributes. The aluminum saturation $(\mathrm{m} \%)$ is high in depth in both soils with higher values in the Non-hydromorphic soil. The levels of aluminum (AlOxa) and Iron (FeOxa) oxalate reduce in depth in both soils, but with greater expressiveness in the hydromorphic soil. The levels of aluminum (AlDit) and iron (FeDit) dithionite increase in depth in the Non-hydromorphic soil and are reduced in the Hydromorphic soil. The ratio of these components is similar between soils in depth, but higher in hydromorphic soil. The levels of Goethite (Gt) and Hematite (Hm) are high in depth in the Non-hydromorphic soil and decrease in the Hydromorphic soil. Isomorphic substitution is similar between soils studied on the surface and in the subsurface. The minerals present in Hydromorphic and Non-hydromorphic soil are similar in all depths analyzed.

\section{References}

Alleoni, L. R., Cerri, C. E., \& Regitano, J. B. (2017). Química e Fertilidade do Solo. Escola Superior de Agricultura "Luis de Queiroz"-Esalq. Departamento de Ciência do Solo, Universidade Federal de Viçosa. 
Retrieved from https://edisciplinas.usp.br/pluginfile.php/4538987/mod_resource/content/1/Apostila\%20T e\%C3\%B3rica\%20final.pdf

Alvarez, V. H. V., \& Ribeiro, A. C. (1999). Calagem. In A. C. Ribeiro, P. T. G. Guimarães, \& V. H. V. Alvarez (Eds.), Recomendações para o uso de corretivos e fertilizantes em Minas Gerais-5 $5^{a}$ aproximação. Viçosa, Brazil. Retrieved from https://www.editoraufv.com.br/produto/5-aproximacao-recomendacoes-para-o-usode-corretivos-e-fertilizantes-em-minas-g/1109073

Aquino, B. F. (2004). Conceitos fundamentais em fertilidade do solo. Fortaleza: UFC. Retrieved from https://www.bdpa.cnptia.embrapa.br

Bahia Filho, A. F. C., Braga, J. M., Resende, M., \& Ribeiro, A. C. (1983). Relação entre adsorção de fósforo e componentes mineralógicos da fração argila de Latossolos do Planalto Central. Revista Brasileira de Ciência do Solo, 7, 221-226. Retrieved from https://core.ac.uk/download/pdf/45495592.pdf

Baldotto, M. A., \& Velloso, C. X. (2014). Eletroquímica de solos modais e de sua matéria orgânica em ambientes tropicais. Revista Ceres, 61, 1012-1021. https://doi.org/10.1590/0034-737X201461060018

Barbosa, T. M. B. (2017). Mineralogia e disponibilidade de fósforo em solos de terra firme da Amazônia Central. Manaus: Universidade Federal do Amazonas. Retrieved from https://tede.ufam.edu.br/handle/tede/6064

Barrow, N. J. (1985). Reaction of anions and cations with variable-charge soils. Advances in Agronomy, 3, 183-230. https://doi.org/10.1016/S0065-2113(08)60676-8

Bünemann, E. K. (2015). Assessment of gross and net mineralization rates of soil organic phosphorus-A review. Soil Biology \& Biochemistry, 89, 82-98. https://doi.org/10.1016/j.soilbio.2015.06.026

CFSEMG (Comissão de Fertilidade do Solo do Estado de Minas Gerais). (1999). Recomendações para o uso de corretivos e fertilizantes em Minas Gerais (2nd ed.). UFLA: Lavras. Retrieved from https://www.sbcs.org. br/loja/index.php?route=product/product\&product_id=133

Cravo, M. S., Smyth, T. J., \& Brasil, E. C. (2012). Calagem em Latossolo amarelo distrófico da Amazônia e sua influência em atributos químicos do solo e na produtividade de culturas anuais. Revista Brasileira de Ciência do Solo, 36, 895-907. https://doi.org/10.1590/S0100-06832012000300020

Cravo, M. S., Veigas, I. J. M., \& Brasil, E. C. (2007). Recomendações de Adubação e calagem para o estado do Pará. Belém: Embrapa Amazônia Oriental. Retrieved from https://www.bdpa.cnptia.embrapa.br

Cunha, J. C., Ruiz, H. A., Betânia, M. V., Bragança, R., \& Fernandes, A. (2014). Quantification of permanent and variable charges in reference soils of the state of Pernambuco. Revista Brasileira de Ciência do Solo, 38, 1162-1169. https://doi.org/10.1590/S0100-06832014000400012

Demattê, J. L. I., \& Demattê J. A. M. (1993). Comparações entre as propriedades químicas de solos das regiões da floresta amazônica e do cerrado do Brasil central. Scientia Agricola, 50, 272-286. https://doi.org/ $10.1590 / \mathrm{S} 0103-90161993000200016$

Embrapa (Empresa Brasileira de Pesquisa Agropecuária). (2017). Manual de métodos de análises de solo (3rd ed.). Rio de Janeiro: Embrapa. Retrieved from https://www.bdpa.cnptia.embrapa.br

Falcão, N. P. S., \& Silva, J. R. A. (2004). Características de adsorção de fósforo em alguns solos da Amazônia Central. Acta Amazônica, 34, 337-342. https://doi.org/10.1590/S0044-59672004000300001

Falesi, I. C. (1984). Estado atual de conhecimentos de solos da Amazônia brasileira. $1^{\circ}$ Simpósio do Trópico Úmido, Belém. Belém: Embrapa Trópico Úmido. Retrieved from https://www.bdpa.cnptia.embrapa.br

Farias, S. C. C., Silva, M. L., Ruivo, M. L. P., Rodrigues, P. G., Melo, V. S., Costa, A. R., \& Souza, J. C. (2016). Phosphorus Forms in Ultisol Submitted to Burning and Trituration of Vegetation in Eastern Amazon. Revista Brasileira de Ciência do Solo, 40, 1-12. https://doi.org/10.1590/18069657rbcs20150198

Ferreira, W. A., \& Botelho, S. M. (1999). Efeito da inundação sobre as propriedades de um gleissolo sálico sódico de várzea do rio dos Morcegos no município de Rimavera, PA. Belém: Embrapa Amazônia Oriental. Retrieved from https://www.bdpa.cnptia.embrapa.br

Fitzpatrick, R. W., \& Schwertmann, U. (1982). Al-substituted goethite-An indicator of pedogenic and other weathering environments in South Africa. Geoderma, 27(4), 335-347. https://doi.org/10.1016/0016-7061 (82) $90022-2$ 
Fox, R. L., \& Sidarle, P. G. E. (1978). Phosphate adsorption by soils of the tropics. In M. Drosdoff (Ed.), Diversity of soils in the tropics (pp. 97-119). American Society of Agronomy, USA. https://oi.org/10.2134/ asaspecpub34.c7

Garcia, C. H. P., Lima, H. N., Silva, F. W. R., Junior, N., Ferreira, A., Teixeira, W. G., Macedo, R. S., \& Tavares, S. G. (2013). Chemical properties and mineralogy of soils with plinthite and petroplinthite in Iranduba (AM), Brazil. Revista Brasileira de Ciência do Solo, 37, 936-946. https://doi.org/10.1590/S0100-06832013 000400011

Gatiboni, L. C., Brunetto, G., Rheinheimer, D. S., \& Kaminski, J. (2013). Fracionamento químico das formas de fósforo do solo: Usos e limitações. Tópicos em Ciência do Solo, 8, 141-187. Retrieved from http://www. scielo.br/scielo.php?script $=$ sci_nlinks\&ref=000095\&pid $=$ S0100-0683201400050000600016\&lng $=p t$

Gérard, F. (2016). Clay minerals, iron/aluminum oxides, and their contribution to phosphate sorption in soils-A myth revisited. Geoderma, 262, 213-226. https://doi.org/10.1016/j.geoderma.2015.08.036

Guilherme, L. R. G., Curi, N., Silva, M. L. N., Brenó, N. B., \& Machado, R. A. F. (2000). Adsorção de fósforo em solos de várzea do estado de Minas Gerais. Revista Brasileira de Ciência do Solo, 24, $27-34$. https://doi.org/10.1590/s0100-06832000000100004

Guimarães, S. T., Lima, H. N., Teixeira, W. G., Neves, A. F., Silva, F. W. R., Macedo, R. S., \& Souza, K. W. (2013). Caracterização e Classificação de gleissolos da Várzea do rio Solimões (Manacapuru e Iranduba), Amazonas, Brasil. Revista Brasileira de Ciência do Solo, 37, 317-326. https://doi.org/10.1590/S0100-0683 2013000200003

Husni, M. H. A., Devi, S., Manas, A. R., Anuar, A. R., \& Shamshuddin, J. (1995). Chemical variables affecting the lime requirement determination of tropical peat soils. Communications in Soil Science and Plant Analysis, 26, 2111-2122. https://doi.org/10.1080/00103629509369433

Kämpf, N., \& Curi, N. (2000). Óxidos de ferro: Indicadores de ambientes pedogênicos e geoquímicos. In R. F. Novais, V. H. Alvarez \& C. E. G. R. Schaefer (Eds.), Tópicos em Ciência do Solo (pp. 107-138). Sociedade Brasileira de Ciência do Solo.

Kiehl, E. J. (1979). Manual de edafologia: relações solos-planta. São Paulo: Agronômica Ceres. Retrieved from https://www.bdpa.cnptia.embrapa.br

Lima, H. N. (2001). Gênese, química, mineralogia e micromorfologia de solos da Amazônia Ocidental. Viçosa: Universidade Federal de Viçosa. Retrieved from https://www.locus.ufv.br/bitstream/handle/123456789/ 7934/texto $\% 20$ completo.pdf? sequence $=1 \&$ isAllowed $=y$

Lima, H. N., Mello, J. W. V., Schaefer C. E. G. R., Ker, J. C., \& Lima, A. M. N. (2006). Mineralogia e química de três solos de uma topossequência da bacia sedimentar do Alto Solimões, Amazônia Ocidental. Revista Brasileira de Ciência do Solo, 30, 59- 68. https://doi.org/10.1590/S0100-06832006000100007

Macedo, R. S. (2009). Atributos físicos, químicos e mineralógicos de solos com horizonte antrópico (Terra Preta de Índio) em área de várzea do rio Solimões, AM. Manaus: Universidade Federal do Amazonas. Retrieved from https://www.alice.cnptia.embrapa.br/alice/bitstream/doc/684876/1/cp131866.pdf

Marques, J. D. O., Teixeira, W. G., Reis, A. M., Junior, O. F. C., Batista, S. M., \& Afonso, M. A. C. B. (2010). Atributos químicos, físico-hídricos e mineralogia da fração argila em solos do Baixo Amazonas: Serra de Parintins. Acta Amazonica, 40, 1-12. https://doi.org/10.1590/S0044-59672010000100001.

Mehra, O. P., \& Jackson, M. L. (1960). Iron oxide removal from soils and clays by a dithionite-citrate system buffered with sodium bicarbonate. Proceedings of Clays \& Clay Mineral Conference, 7, 317-327. https://doi.org/10.1346/CCMN.1958.0070122

Melo, V. F., \& Alleoni, L. R. F. (2009). Química e mineralogia do solo (2nd ed.). Viçosa: Sociedade Brasileira de Ciência do Solo. Retrieved from https://www.bdpa.cnptia.embrapa.br

Möller, M. R. F. (1991). Substituição isomórfica em óxidos de ferro de Latossolos da Amazônia e suas implicações na sorção de fósforo. Piracicaba: Esalq. Retrieved from https://teses.usp.br/teses/disponiveis/ 11/11140/tde-20200111-134528/publico/MollerMariaReginaFreire.pdf

Moreira, M. L. C., \& Vasconcelos, T. N. N. (2007). Mato Grosso: solos e paisagens. Cuiabá: Entrelinhas. Retrieved from https://www.bdpa.cnptia.embrapa.br

Novais, R. F., Smyth, T. J., \& Nunes, F. N. (2007). Fósforo. In R. F. Novais, V. H. Alvarez, N. F. Barros, R. L. F. Fontes, R. B. Cantarutti, \& J. C. L. Neves (Eds.), Fertilidade do solo. Minas Gerais: Sociedade Brasileira de 
Ciência do Solo. Retrieved from http://www.scielo.br/scielo.php?script=sci_nlinks\&ref=000103\&pid=S0 $100-0683201400040001800016 \& \operatorname{lng}=\mathrm{pt}$

Oliveira, D. M., Damaceno, J. B. D., Lobato, A. C. N., Guimarães, R. S., Júnior, J. L., Guerrini, I. A., \& Falcão, N. P. S. (2019). Biochar of Bamboo Influencing the Availability of P from Different Phosphate Sources in Dystrophic Yellow Oxisol of Amazon. Journal of Agricultural Science, 11(9), 242-251. https://doi.org/ $10.5539 /$ jas.v11n9p242

Rodrigues, T. E. (1996). Solos da Amazônia. In: Alvarez, V. H., Fontes, L. E .F.; Fontes, M. P. F. O solo nos grandes domínios morfoclimáticos do Brasil e o desenvolvimento sustentável. Viçosa: Sociedade Brasileira de Ciência do Solo. Retrieved from https://www.bdpa.cnptia.embrapa.br

Sanchez, P. A., \& Salinas, J. G. (1981). Low input technology for managing Oxisols and Ultisols in tropical America. Advances in Agronomy, 34, 280-406. https://doi.org/10.1016/S0065-2113(08)60889-5

Santos, H. G., Jacomine, P. K. T., Anjos, L. H. C., Oliveira, V. A., Lumbreras, J. F., Coelho, M. R., ... Cunha, T. J. F. (2018). Sistema Brasileiro de Classificação de Solos (5th ed.). Brasília, DF: Embrapa. Retrieved from https://www.bdpa.cnptia.embrapa.br

Santos, R. D., Santos, H. G., Ker, J. C., Anjos, L. H. C., \& Shimizu, S. H. (2015). Manual de descrição e coleta de solo no campo (7th ed.). Viçosa: SBCS. Retrieved from https://www.bdpa.cnptia.embrapa.br

Schaefer, C. E. G. R., Lima, H. N., Teixeira, W. G., Vale Junior, J. F, Souza, K. W., Correira, G. R., .. Ruivo, M. L. (2017). Solos da Amazônia. In N. Curi, J. C. Ker, R. F. Novais, P. Vidal-Torrado, \& C. E. G. R. Schaefer (Eds.), Pedologia-Solos dos Biomas Brasileiros. Viçosa: Sociedade Brasileira de Ciência do Solo. Retrieved from https://www.bdpa.cnptia.embrapa.br

Schwertmann, U. (1964). The differentiation of iron oxide in soil by a photochemical extraction with acid ammoniun oxalate. Zeitschrift fuer Pflanzenernaehrung und Bodenkunde, 105, 104-201. Retrieved from http://www.scielo.br/scielo.php?script=sci_nlinks\&ref=000067\&pid=S0100-0683200100040001900025\&ln $\mathrm{g}=\mathrm{en}$

Schwertmann, U. (1966). Inhibitory effect of soil organic matter on the crystallization of amorphus ferric hidroxide. Nature, 212, 645-646. https://doi.org/10.1038/212645b0

Silva, F. W. R., Lima, H. N., Teixeira, W. G., Motta, M. B., \& Santana, R. M. (2011). Caracterização química e mineralogia de solos antrópicos (Terra Pretas de Índio) na Amazônia Central. Revista Brasileira de Ciência do Solo, 35, 673-681. https://doi.org/10.1590/S0100-06832011000300002

Sombroek, W. G. (1966). Amazon Soils-A reconnaissance of the soils of the Brazilian Amazon region. Wageningen: Center for Agriculture Publications and Documentation. Retrieved from https://library.wur.nl/ WebQuery/wurpubs/421842

Spanner, G. C., Neves, É. S., Nascimento, J. C., Miléo, J. A. C., \& Silva, S. A. S. (2014). Determinação dos aspectos morfológicos do Solo e dendrológicos da vegetação em uma topossequência, em Altamira-PA. Revista Agrarian Academy, 1, 37-46. https://doi.org/10.18677/Agrarian_Academy_2014_028

Tan, K. H. (1982). Principles of soil chemistry. New York: Marcel Dekker. Retrieved from http://www.scielo.br/ scielo.php?script $=$ sci_nlinks\&ref $=000148 \&$ pid $=S 1415-4366201100110000400024 \& \operatorname{lng}=\mathrm{pt}$

Teixeira, J. B. S., Sousa, R. O., \& Vale, M. L. C. (2018). Phosphorus adsorption after drainage in two soil classes. Revista Ceres, 65, 196-203. https://doi.org/10.1590/0034-737x201865020012

Teixeira, W. G., Arruda, W., Shinzato, E., Macedo, R. S., Martins, G. C., Lima, H. N., \& Rodrigues, T. E. (2010). Solos do Estado do Amazonas. In M. A. M. Maia, \& J. L. Marmos (Eds.), Geodiversidade do Estado do Amazonas. Manaus: CPRM. Retrieved from http://rigeo.cprm.gov.br/xmlui/handle/doc/16624

Teixeira, W. G., Cruz, M. E. G., Lima, H. N., Correia, M. R. D., \& Soares, C. B. (2007). Mapa de Solos do Município de Iranduba (Escala 1:200.000). Mapas Pedológicos de Municípios do Médio Solimões: Área de Estudo do Piatam-Embrapa, UFAM, SIPAM. Manaus: EDUA. Retrieved from http://www.scielo.br/ scielo.php?script $=$ sci_nlinks\&ref $=000127 \& p i d=S 0100-0683201100030000200026 \& \operatorname{lng}=p t$

Teles, A. P. B., Rodrigues, M., \& Bejarano Herrera, W. F. (2017). Do cover crops change the lability of phosphorus in a clayey subtropical soil under different phosphate fertilizers? Soil Use and Management, 33, 34-44. https://doi.org/10.1111/sum.12327

Tucci, C. A. F. (1991). Disponibilidade de fósforo em solos da Amazônia. Viçosa: Universidade Federal de Viçosa. Retrieved from https://www.bdpa.cnptia.embrapa.br 
Uehara, G. (1979). Mineralo-chemical properties of Oxisols. International Soil Classification Workshop, 2 , Bangkok. Anais... Bangkok, Soil Survey Division, Land Development. Retrieved from http://agris.fao.org/ agris-search/search.do?recordID=US201301966261

USDA (United States Department of Agriculture). (2011). Keys to Soil Taxonomy (11th ed.). Retrieved from https:/www.nrcs.usda.gov/wps/portal/nrcs/detail/soils/survey/class/taxonomy/?cid=nrcs142p2_053580

Vale Júnior, J. F., Souza, M. I. L., Nascimento, P. P. R. R., \& Cruz, D. L. S. (2011). Solos da Amazônia: etnopedologia e desenvolvimento sustentável. Revista Agro@mbiente, 5, 158-165. Https://doi.org/10.18227/ 1982-8470ragro.v5i2.562

Yan, J., Jiang, T., Yao, Y., Lu, S., Wang, Q., \& Wei, S. (2016). Preliminary investigation of phosphorus adsorption onto two types of iron oxide-organic matter complexes. Journal of Environmental Sciences, 42, 152-162. https://doi.org/10.1016/j.jes.2015.08.008

Yang, X., Post, W. M., Thornton, P. E., \& Jain, A. (2013). The distribution of soil phosphorus for global biogeochemical modeling. Biogeosciences, 10, 2525-2537. https://doi.org/10.5194/bg-10-2525-2013

\section{Copyrights}

Copyright for this article is retained by the author(s), with first publication rights granted to the journal.

This is an open-access article distributed under the terms and conditions of the Creative Commons Attribution license (http://creativecommons.org/licenses/by/4.0/). 